STUDIES IN ENGLISH LITERATURE

Volume XXXVI 



\section{MIDDLE ENGLISH PROSE STYLE}

Margery Kempe and Julian of Norwich

by

ROBERT KARL STONE

The University of Wisconsin-Milwaukee

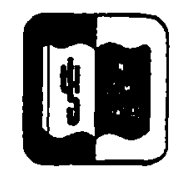

1970

MOUTON

THE HAGUE - PARIS 
(c) Copyright 1970 in The Netherlands.

Mouton \& Co. N.V., Publishers, The Hague.

No part of this book may be translated or reproduced in any form, by print, photoprint, microfilm, or any other means, without written permission from the publishers.

LIBRARY OF CONGRESS CATALOG CARD NUMBER : 69-10748

Printed in The Netherlands by Mouton \& Co., Printers, The Hague. 
For Shirley, Bill, and Bob 
